\title{
Knowledge Management and Team Effectiveness; Investigating the Role of Employee Performance and Person Job Fit
}

\author{
* Dr. Muhammad Zia-ur-Rehman, Associate Professor (Corresponding Author) \\ ** Ms Sana Tariq, Independent Researcher \\ *** Dr. Sumeera Imran, Assistant Professor
}

\begin{abstract}
The present study aims to investigate the role of knowledge management that contributes towards the effectiveness of teams and also to determine the behaviors of Employee performance and person Job fit. The study provides a positive outlook on the effects of Knowledge management on Team effectiveness. The number of questionnaires distributed were 280, out of which 147 were received so the rate of response is 52.5\%. Non-probability convenience sampling is employed. The tool employed for data analysis is Smart-PLS. Descriptive analysis, PLS algorithm, and bootstrapping were calculated. The results show that there is a positive association between Knowledge management and
\end{abstract} Employees' performance $(p=0.000)$.

Keywords: Employee Performance, Knowledge Management, Person Job Fit, Team

\section{Introduction}

Nowadays, there is great interest in studying organizational teams. This interest is concerned with the increasing use of teams in companies. The use of teams has expanded dramatically in response to competitive challenges and organizational needs of flexibility and adaptation. Understanding effectiveness is a key issue in team research. In this sense, several models related to knowledge management, have been developed with an objective: to identify multiple factors of effectiveness and their relationships with success.

Traditionally, people search for jobs within their vocational fields of interest. Research has supported the notion that job seekers try to match their abilities to the tasks on the job (Ledford, \& Hathan A \& Ashforth, 1997). Job seekers often decide which job to do based on how well they can perform the required task. This concept is called person-job (P-J) fit. This study has led us to believe that job seekers are looking for more than fit with the job.

\section{Problem Statement}

Most of the workplace teams are built upon the basis of the technical knowledge that each member of the team possessive, whereas very little is known about the non-technical factors and how they impact the creation of teams (Lucius and Kuhnert 1997). It is said that if the team does not reach the set goals, problems are often blamed on 'poor communication,' an overly broad label for a range of personality differences that can create tensions and misunderstandings (Culp and Smith 2001). Lacking in knowledge, skill, and ability might seem like the major of teams failing but managers agree these aren't but they say that dissatisfaction and not being in the right team has major impacts on teams failing.

\section{Literature Review}

\section{The concept of Team Effectiveness}

The atmosphere in which organizations are working today is changing quickly and it can be said that those teams that are innovative and ready to try new things are preferred as they bring to the table ideas that can help the organization fly to new heights (Gilson \& Shalley, 2004). To counter the quickly changing environment with new technologies, laws, and competition affecting firms all the time, it is said that creativity is the tool that a firm must use. The use of creativity has been an

\footnotetext{
* National Defence University, Islamabad Email: drziaofficial@ gmail.com

** National Defence University, Islamabad Email: Sanatariq@gmail.com

*** National Defence University, Islamabad Email: $\underline{\text { SumeeraImran@hotmail.com }}$
} 
important part of team effectiveness for a long time as it allows firms to innovate and invent (Hackman \& Morris, 1975; Stein, 1975). Furthermore, a couple of studies related to knowledge management have theorized that creativity is responsible for improving performance but no study has extensively tested that (Woodman et al., 1993; Amabile, 1996).

Hackman (2002) in his paper says that there is no difference between "team" and "group": as he has written, "Although some authors, such as Katzenbach and Smith, 2002, take great care to distinguish between the terms team and group, I do not. I use the terms interchangeably and make no distinction whatever between them". Cohen and Bailey (1997) have also used both words without any differentiation.

Team effectiveness is the team's ability to produce goods at par or above par levels. Team member judgment of effectiveness (TMJE), team member job satisfaction (TMJS), and manager judgment of effectiveness (MJE) are all assessments, which are used by firms to measure and manage the effectiveness of the teams in an organization.

\section{The concept of Knowledge Management}

The body of knowledge, formal as well as informal that is essential to the continuous and effective functioning of the agency at all levels. Knowledge management is the procedure from collecting knowledge to using it effectively for the betterment of the organization (Davenport et al. (1998). O'Dell and Grayson (1998) defined it as a process that ensures that the transfer of knowledge happens at the right time between the right people so that the information can be used to benefit the firm. Knowledge is one of the few things that the competitors cannot quickly and easily copy hence it is an important resource (Barney, 1991). This supports Teece's (2001) argument that the organization can only get a competitive edge once it can produce and protect knowledge that is not easily copied. Therefore, it can be said that knowledge brings in innovation and invention while also being vital for the enhancement of skills.

Jacobson (2009) says that the creation of knowledge happens when we share knowledge as it takes various forms. We can find knowledge in various forms in an organization that the employees might use to benefit themselves and the organization for example codified (Hendrik 2008). By creating knowledge an organization can forward themselves as well as help its employees in enhancing their skills, and reducing the time needed to complete the given assignment (Haas \& Hansen, 2008). As the workers have tacit knowledge that cannot easily be imitated, which makes knowledge workers a valuable resource, which not only is beneficial for the workers but also for the firm. If knowledge workers are not given the adequate information they require from the firm then slowly the workers will separate themselves from the firm moving to other organizations.

If knowledge is managed well around the goals of the organization then the value of knowledge increases. After discussing the importance of knowledge, we can say the knowledge management set a goal to use knowledge as the source of growth for the firm so that the firm can get a competitive advantage (Dimitriades, 2005). Usually, the process of creation of knowledge and then further transfer of it to the right person at the right time is called knowledge management (KM), there have been studies that link KM to better performance (Hlupic et al., 2002). This suggests by using $\mathrm{KM}$ the managers can help expand the organization and reach the goals set (Riege and Lindsay, 2006).

In KM the major role is played by business strategy while IT plays a supporting role (Ponzi, 2002).IT literature was only for understanding the Information Technology system better but also played a big role in knowledge management. But still, the observations in media showed that there was a decreased interest in KM that can be since the investments into KM were not giving a return as high as expected but also because at the dot com dream was blown up (Ponzi, 2002).

\section{Person Job Fit (PJF)}

Edwards (1991) says that most detailed researches on PJF look into whether the skills that the person (employee's side) brings fit the requirements of the organization (organization's side). P-J fit is achieved when there is the closeness of a person's ability and the requirements of the existing job, that is, an individual has the knowledge which can aid him in completing the tasks. Additionally, Lawrence (2004) described it as a potential match between an employee's supply of skills and the job's want.

Thus, to increase productivity and motivation we ought to try to match the person to the job (Edwards, 1991). Furthermore, many empirical types of research in social sciences have led Bhat and 
Rainayee2019) to believe that person-job fit is crucial for a good outcome. A direct link has been established between PJF and performance, satisfaction at work, and commitment to the organization (Saks \& Ashforth, 2002). It is argued that if the job is the best fit for the employee then one can see the enhanced performance (Bhat, 2014). Caldwell and O'Reilly (1990) state that satisfaction and performance will increase as the job becomes a better fit. Furthermore, PJF is said to be directly related to gratification and satisfaction alongside loyalty to the firm (O'Reilly, Chatman \& Caldwell, 1990).

Edwards (1991) used the PJF term while including the demand-abilities perspective and the need-supplies viewpoint. It further divides the P-J fit. To describe them both, one focuses on the skills of an individual and what the tasks require whereas the investigator wishes or demand of a person and characteristics required to complete the job. These both are called complementary fit. In the other model, which is defined as supplementary, the people are used to describe the environment, not the job hence it may not properly link to PJF. The need-supplies perspective is made up of the demands of the potential employee and the characteristics of the task that are needed to fulfill those wishes.

The demands-abilities perspective is made up of the job requirements that will complete the requirements of the job and the individuals' skills that will be used to finish the job. Job demand is the skills and abilities that an employee needs to possess to complete the job to a par level (Caldwell \& O'Reilly, 1990; Wilk \& Sackett, 1996). Experience, knowledge \& aptitude can be classified as the abilities required (Caldwell \& O'Reilly, 1990). On the other hand, for the company to measure PJF the techniques used include CV, face-to-face interview, references, aptitude tests, and various other methods (Werbel \& Gulliland, 1999).

A match between a potential employee's qualifications and the requirements of the job may lead to an increase in his/her expectancy of a job offer. Saks and Ashford (1997) describe PJF as the classical notion of person-situation fit in which potential employees equate their skills and abilities to those required by the task. Furthermore, Edwards (1991) called PJF the demands-abilities fit because it matches persons' skills and the skills needed by the profession.PJF can be said to be a match between the potential employee, and the skills needed by the job. The tasks a person is expected to accomplish in exchange for employment, as well as the characteristics of those tasks is how Kristof (1996) defined job. According to the above definitions, person-job fit appears to be based upon the tasks performed on the job rather than the organization in which it exists (Kristof, 1996).

Along the same lines, Chatman (1989) recognized that individuals are also selecting more than a job, rather they are selecting an organization for which to work. Specifically, research has supported her view in that job seekers tend to choose organizations based on the similarity between their values and organizational values (Hall, Schneider \& Nygren, 1970). Further, Wanous (1980) refers to the final job decision as to the "organizational choice" rather than the "job choice". According to Wanous, individuals are interested in creating fit within the climate of the organization. Lastly, Ashforth and Saks (1997) suggested that a successful job is not only limited to matching the skills to the job but to the organization as a whole so that you can be more productive in the organization.

\section{Employee's Performance as a Concept}

Employee performance is a veritable tool in achieving optimum performance by organizations. June, Kheng, and Mahmood (2013) state that one of the crucial factors that can impact the end performance of an organization is the performance of the employee. It also plays a part in determining the competitive edge the firm has (Dessler, 2011). Employee performance includes all such motions of the employees at work which directly or indirectly lead to the fulfillment of the mission of the organization (Viswesvaran \& Ones, 2000), All activities that directly contribute to the technical center of the firm (Borman \& Motowidlo, 1997)

The outcome is usually the basis to measure employee performance. But behavior can also be used for this. And as it is evident that an organization sets standards against which the performance of the employee is measured. Several measures can be used to measure the performance of the employee. One of which is profitability. This is the ability to earn more revenue than cost consistently over a period. There are several ways to express it, as a ratio to revenue or the employed capital (Wood \& Stangster 2002). After profitability, another measure is efficiency and effectiveness. Efficiency is aimed at reducing waste by producing desired goods while using the least amount of resources while effectiveness is to meet the goals set by employers for employees (Stoner 1996). One 
more measure is productivity. Productivity is output divided by input, for example, if a worker uses 3 trees to make 6 chairs, his productivity is 2 (Stoner, Freeman and Gilbert Jr 1995. Quality can be described as the ability of produced goods to satisfy the needs of the consumers demanding that well (Kotler \& Armstrong 2002). Another way to define quality can be to continuously achieve a better product while simultaneously keeping the price competitive (Stoner 1996).

In the industrial setting, the extent to which the employee is helping the firm reach its longterm mission and vision is called performance. So good performance means that the employee was able to help the organization reach its strategic goals. In service sectors, employees are most important as they are the basic resource that provides the firm with a competitive edge (Luthans \& Stajkovic, 1999; Pfeffer, 1994). Furthermore, a commitment performance approach sees employees as an integral part of the organization and listens to their concerns and ideas. Organizational performance depends majorly on how the employee has been performing in the given period. These are directly related. Employee performance is described employee's willingness to do or not do tasks. Attitude and quantity and quality of the produced goods all come under the umbrella of employee performance (Güngör, 2011).

\section{Knowledge Management and Employee's Performance}

Jantunen (2005) states that information a valued part of the strategic part of an organization as it can't be imitated easily so it provides an advantage to the firm. In fact, for a firm's activities, knowledgebased intangible assets, and learning capabilities of the firms are very important (Jantunen, 2005). Knowledge management uses knowledge as an asset that will help the employees to collaborate and innovate in such a way that helps the business reach its goals and provides the firm with a competitive advantage (June, 2005). Data is usually taken to be the most vital part of a firm (Choe, 2004), and knowledge is not location bound, in the sense that its advantages and disadvantages are not restricted by geographical borders (Singh et al., 2008).

During the 1990s, according to many studies, self-directedness played a vital part for firms (Calder \& McCollumn, 1998; Robinson \& Arthy,, 1999; Edwards, 1995). Those firms wishing to gain competitive advantage must aim at workers who possess self-directedness (Smith et al., 2007).

$\boldsymbol{H}_{1:}$ There is a positive and significant association of Knowledge management on Employees' performance

\section{Employee's Performance and Team Effectiveness}

Kay et al. (2008) state that the situational approach depends on the manager's ability to reconcile any control that is lost by delegating power and the need to reach goals, making it a dilemma. Furthermore, the situational approach doesn't take the mental state of employees into account. Just giving them the power to decide doesn't mean they will be willing to work hard. Claim that "delegating or resource sharing is only one set of conditions that may (but not necessarily) enable or empower subordinates" (Conger \& Kanungo, 1988; p. 474) but also disagrees with the presented method "does not adequately address the nature of empowerment as experienced by subordinates" ( $p$. 472). The situational approach delegates the power to the employee whereas the psychological approach attempts to enhance feelings...

A study was able to decode the relationship between how much power is delegated to an employee and how well the employee performs. Researches usually have not focused on quantitative methods in the past. As previous efforts have not been made to deeply understand the psychology behind work teams and we don't know the impacts of the delegation of power on them, this research will contribute to such effects on work teams in an office context and will be a very important contribution.

\section{$\boldsymbol{H}_{2}$ : There is a positive and significant effect of Employee's performance on Team effectiveness.}

\section{Person Job fit on Employee Performance and Team Effectiveness}

Team effectiveness refers to the number of goals set for the teams such as productivity are reached by the members. However, team effectiveness, according to group researchers, also includes indirect effects on team members such as how fit the team is for each other and the satisfaction of each member (Shea \& Guzzo, 1987). We say that effectiveness is not only for the overall team but for each member of the team. Job satisfaction mainly imitates the motivational and emotional side, and learning represents how much an individual gain in terms of knowledge. In terms of the team, satisfaction means the fulfillment of social needs that each human has and the willingness to stay with 
the same team (Cordery, 1996; Hackman, 1987). When a firm increases its ownership of intangible assets we refer to it as gaining knowledge (Cordery, 1996; Jackson, 1996).

$\boldsymbol{H}_{3}$ : There is an influence of Person job fit on the relationship between Employee performance and Team effectiveness.

\section{Knowledge Management and Team Effectiveness}

A lot of studies focused on the term 'blue-collar' worker (Cordery, Mueller, \& Smith, 1991). Whereas not many studies investigate the segment that is evolving and gaining popularity quickly that is of knowledge workers and are more likely to be a part of a team compared to blue-collar workers (Beyerlein, Johnson, \& Beyerlein, 1995). Those workers who have gained advanced knowledge via formal education that apply such knowledge towards the production of goods and services can be called knowledge workers (Drucker, 1994).

$\boldsymbol{H}_{5}:$ There is a positive and significant impact of knowledge management on Team effectiveness

Figure - 1 Conceptual Framework

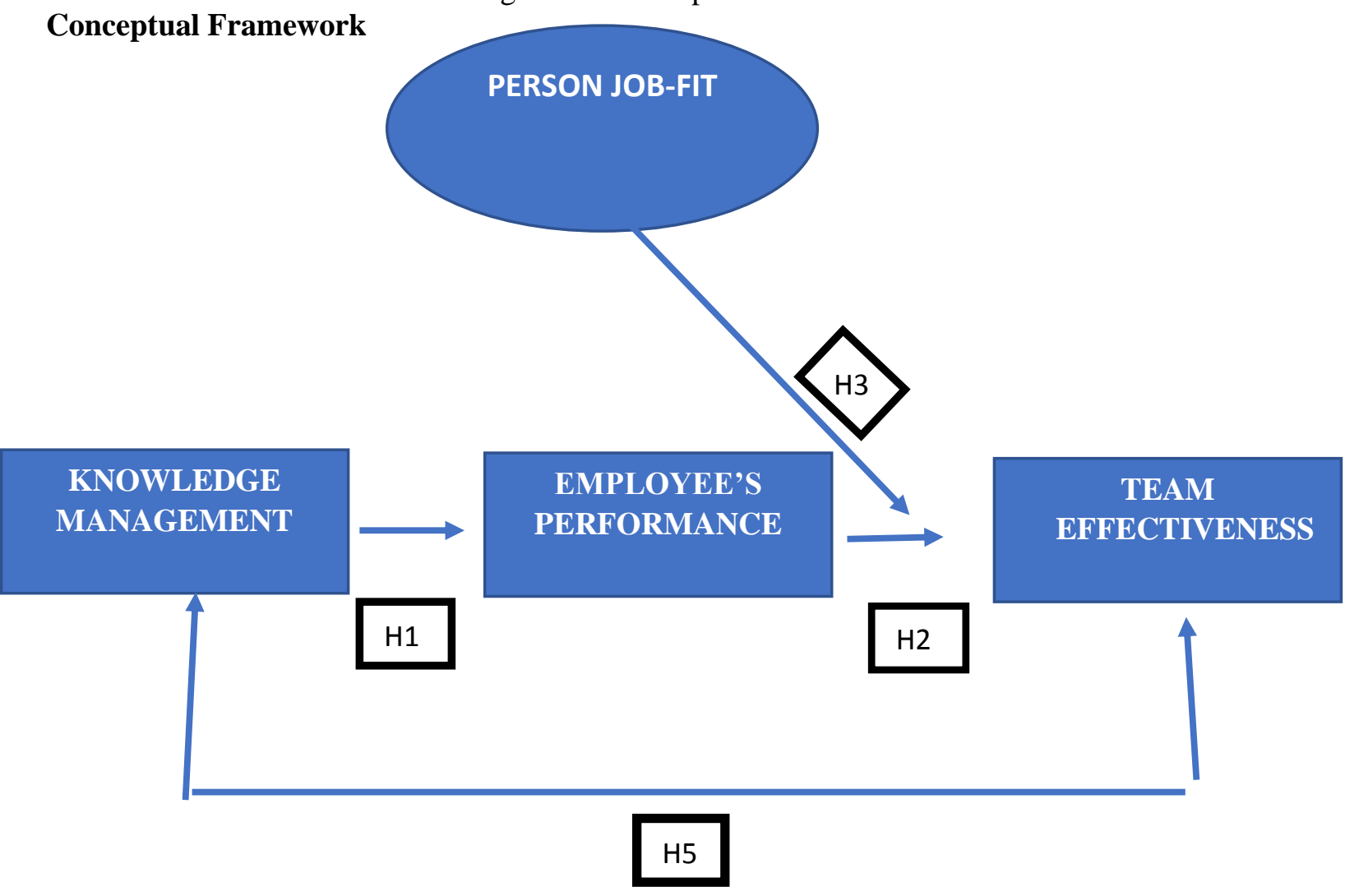

$\mathbf{H}_{1}$ : There is a positive and significant association of Knowledge management on Employees' performance

$\mathbf{H}_{2}$ : There is a positive and significant effect of Employee's performance on Team effectiveness.

$\mathbf{H}_{3}$ : There is an influence of Person job fit on the relationship between Employee performance and Team effectiveness.

$\mathbf{H}_{4}$ : Employee performance act as a mediator between knowledge management and team effectiveness.

$\mathbf{H}_{5}$ : There is a positive and significant impact of knowledge management on Team effectiveness

\section{Methodology and Analysis}

The research design applied to the study decides that how will be the analysis process of the research. The whole research design encompasses research structure, sample size chosen to conduct the study, and the type of instrument or scale used to measure the variables.

This study is focused on investigating the relation of Knowledge management on team effectiveness, analyzing the moderating role of person-job fit and mediation of employee performance. It focuses on the relation of knowledge management which enhances the team effectiveness through the performance of employees. Knowledge management is the independent 
variable, Team effectiveness is the dependent variable whereas employee performance is a mediator and a person-job fit is a moderator.

\section{Sampling and Population}

The sample used for this study is the people working in Private Banks of Pakistan (Islamabad/Rawalpindi). More specifically the Branch Managers, Loan Officers, and bank tellers were studied.

As the topic explains that the study in a service-oriented organization with such variables was not explored before here in Pakistan. The knowledge management process in the service-oriented organization of Pakistan is usually ignored that how the performance of employees enhances the effectiveness of the team they are working in. The numbers of questionnaires distributed were 280, out of which 147 were received so the rate of response is $89 \%$ which is of great success for this research.

$$
\begin{aligned}
& \text { Response Rate }=\underline{\text { Response Collected }} \quad \text { x } \quad 100 \\
& \text { Questionnaires Distributed } \\
& =\frac{147}{280} \times 100
\end{aligned}
$$

Response Rate $=52.5$ the relationship between knowledge management, team effectiveness, person-job fit, and employee performance has been evaluated within various dimensions of these variables. Several statistical techniques have been employed to determine associations and independence between performances in these two fields based on facts and figures collected through questionnaires. Furthermore, the results have also filtered key information about respondents which have been utilized in analysis through SPSS and smart pls.

Non-probability sampling is used for the present research. The technique of sampling used is called convenient sampling. The aim was to cover the maximum number of employees of various private banks in Rawalpindi \& Islamabad. The Bank managers to bank tellers of the private banks are taken as a sample due to these accurate results are formed.

\section{Analysis}

The relationship between knowledge management, team effectiveness, person-job fit, and employee performance has been evaluated within various dimensions of these variables. Several statistical techniques have been employed to determine associations and independence between performances in these two fields based on facts and figures collected through questionnaires. Furthermore, the results have also filtered key information about respondents which have been utilized in analysis through SPSS and smart pls.

\section{Data Collection}

A questionnaire having 147 items addressing four variables was designed to collect data from private banks of Islamabad and Rawalpindi. In addition to items questions related to demographics were also included in the questionnaire. Questionnaires were distributed among employees of private banks. Questionnaires were distributed individually in all the banks. It took over 300 days to collect the data from respondents. Data was received on the spot or were collected after a few days.

\section{Data screening}

Before performing any analysis to ensure that data is correct and error-free the process adopted is known as data screening. It is used to inspect the data for errors and to correct it before performing any analysis. It is to deal with missing data, check raw data, and identify outliers. Questionnaires received back from respondents were 160 in total. Data were screened through SPSS 21 and found it error-free to conduct analysis. During data entry, 13 questionnaires were found incomplete and rejected. Data of 147 respondents was used for analysis

\section{Descriptive Statistics}

The total population of private banks located in twin cities was surveyed and 147

Responses have been received. The acquired data gives information about respondents

Demographical characteristic 


\begin{tabular}{ccccc}
\hline \multicolumn{5}{c}{ Table-1 Descriptive Statistics (Age) } \\
\hline \multirow{4}{*}{ Valid } & Frequency & Percent & Valid Percent \\
\cline { 2 - 5 } & below 30 & 53 & 36.1 & 36.1 \\
& $31-40$ & 65 & 44.2 & 44.2 \\
& $41-50$ & 26 & 17.7 & 17.7 \\
& above 50 & 3 & 2.0 & 2.0 \\
Total & 147 & 100.0 & 100.0 \\
\hline
\end{tabular}

The selected 147 members have been divided into four different age groups, and the above table shows that the employees below 30 were $36.1 \%$, the employees between $31-40$ years age group were $44.2 \%, 41-50$ years age group were $17.7 \%$, and employees above 50 years were 2.0.

Table-2 Descriptive Statistics (Gender)

\begin{tabular}{lllll}
\hline \multirow{4}{*}{ Valid } & & Frequency & Percent & Valid percent \\
\cline { 2 - 5 } & Male & 102 & 69.4 & 69.4 \\
& Female & 45 & 30.6 & 30.6 \\
& Total & 147 & 100.0 & 100.0 \\
\hline
\end{tabular}

The selected 147 members have been divided into two gender groups (Male/Female). This shows that 102 faculty members are males which represent $69.4 \%$ of the total population. 45 faculty members were females which represent $30.6 \%$ of the population.

Table-3 Descriptive Statistics (Education)

\begin{tabular}{lllll}
\hline & & Frequency & Percent & Valid percent \\
\cline { 2 - 5 } Valid & Bachelor's degree & 23 & 15.6 & 15.6 \\
& Master's degree & 121 & 82.3 & 82.3 \\
& Higher studies & 3 & 2.0 & 2.0 \\
& Total & 147 & 100.0 & 100.0 \\
\hline
\end{tabular}

The above table shows the frequency distribution of the employee's qualification.it is divided into three groups in which the employees with bachelor's degree ae $15.6 \%$, employees who had completed their Master's degree are $82.3 \%$ and with higher studies (MS/M.Phil.) is only $2.0 \%$.

Table-4 Descriptive Statistics (Experience)

\begin{tabular}{lllll}
\hline & & Frequency & Percent & Valid percent \\
\cline { 2 - 5 } Valid & Less than one year & 21 & 14.3 & 14.3 \\
& 1-5 years & 70 & 47.6 & 47.6 \\
6-10 years & 44 & 29.9 & 29.9 \\
11-15 years & 3 & 2.0 & 2.0 \\
16 years and above & 9 & 6.1 & 6.1 \\
Total & 147 & 100.0 & 100.0 \\
\hline
\end{tabular}

The Job experience of bank employees was divided into five groups depending on the number of years in which they have gained experience. The employees with less than one year experience were $14.3 \%$, and employees having 1-5 years of experience were $47.6 \%$, employees with 6-10 years' experience were $29.9 \%, 11-15$ years experienced employees were 2.0 and employees with the experience of 16 years and more were $6.1 \%$ 


\section{Figure-2 the Measurement Model}

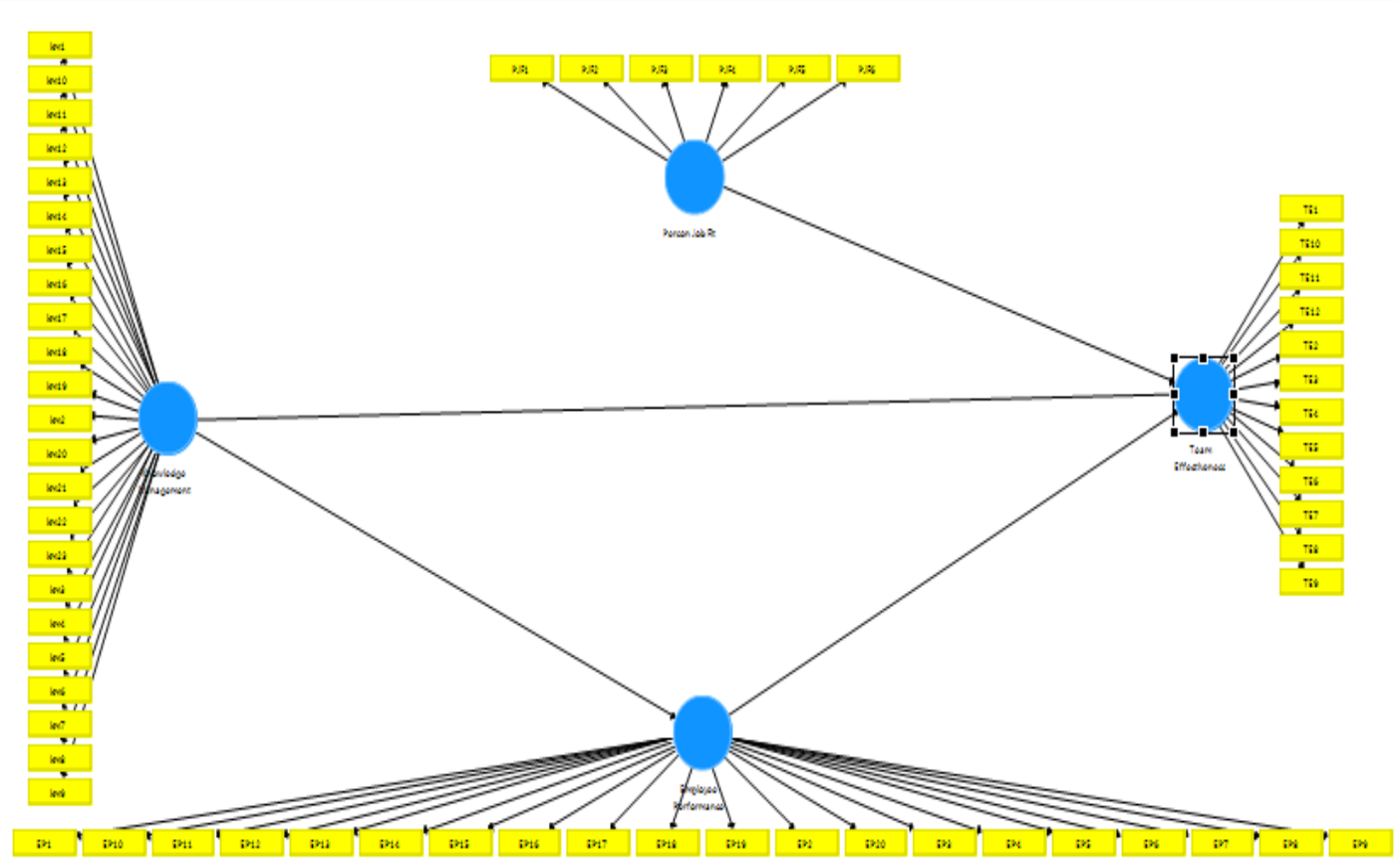

The above figure is the next step of the measurement model where the test for reliability and validity is run and the values of each linkage are calculated. In this way, the values are checked whether there is a need to drop the values or not.

\section{Figure - 3 Final Fitted Model- Measurement model}

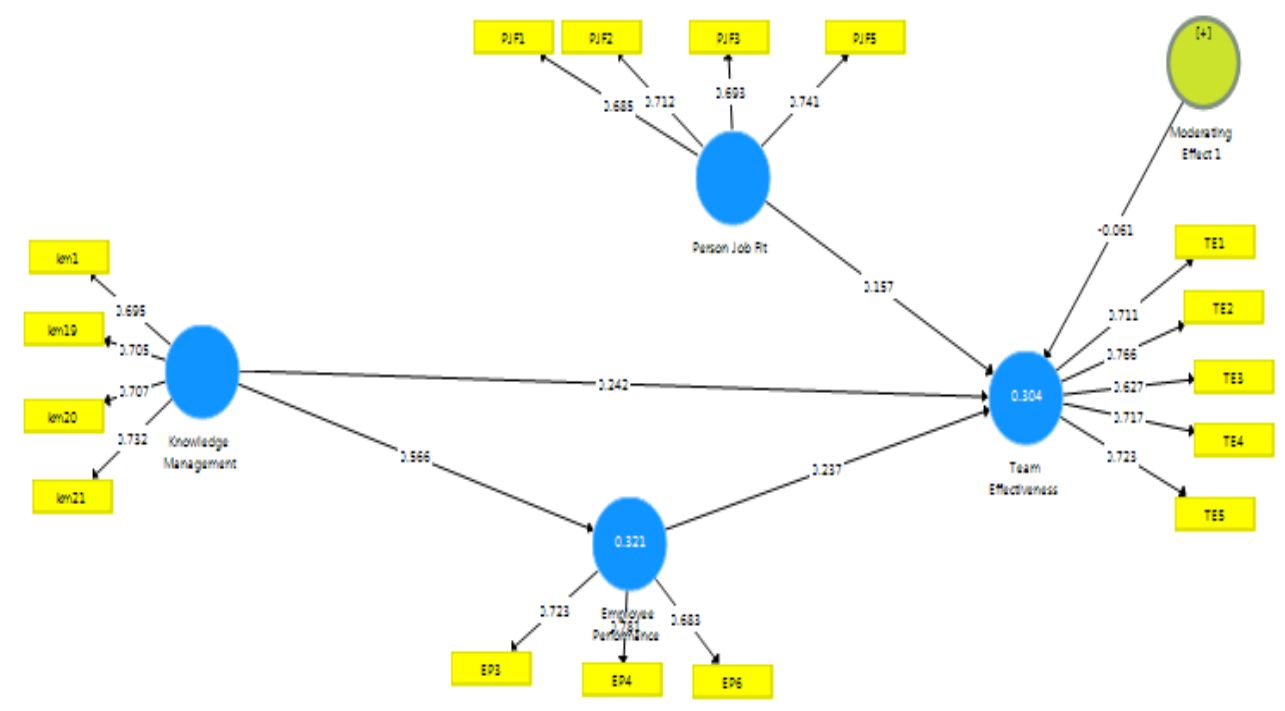

Here is the final fitted model, as the moderation is applied and all the values below 0.5 are dropped to get accurate results. In the end, tests are run and final results are calculated.

\section{Construct Validity and Reliability}

According to Nunnally (1978) rule of Cronbach alpha where the variables should have at least 0.7 values or more then it is more reliable. Here employee performance is 0.560 which is less reliable, knowledge management is 0.672 which is more near to 0.7 and reliable, Person job fit is 0.675 which shows it's reliability is more than EP and KM, the most reliable variable here is Team effectiveness whose Cronbach's alpha value is 0.757 .

And the composite reliability threshold 0.70 given by (hair et al., 1998), here the ICR of all the variables is more than 0.70 as the composite reliability of Employee performance is 0.774 , Knowledge management is 0.802 , the person-job fit is 0.803 and team effectiveness is 0.835 . 
According to Fornel \& lacker, 1981; hair et al, .1998 the AVE should be 0.5 or more hence. As the AVE of all the variables in the above table is more than 0.5 it means that the measure correlates with the other measure of the construct.

\section{Discriminant Validity}

In Fornell and Larcker criterion and Heterotrait-monotrait (HTMT) ratio of correlation, the loading for each block (latent variable) of indicator variables is loading higher for its reflective latent variables than indicators for other latent variables. Those denoted by the values in bold across latent variables are its indicator variables. Here the loading starts from EP which is the highest 0.730, as it goes down to 0.722 in KM while going down the loading of person-job fit if 0.712 and goes down to 0.710 again in team effectiveness.

In the structural model, this is the first step where the moderating effect is applied and linkages are connected between the variables.

Figure -4 Structural Model

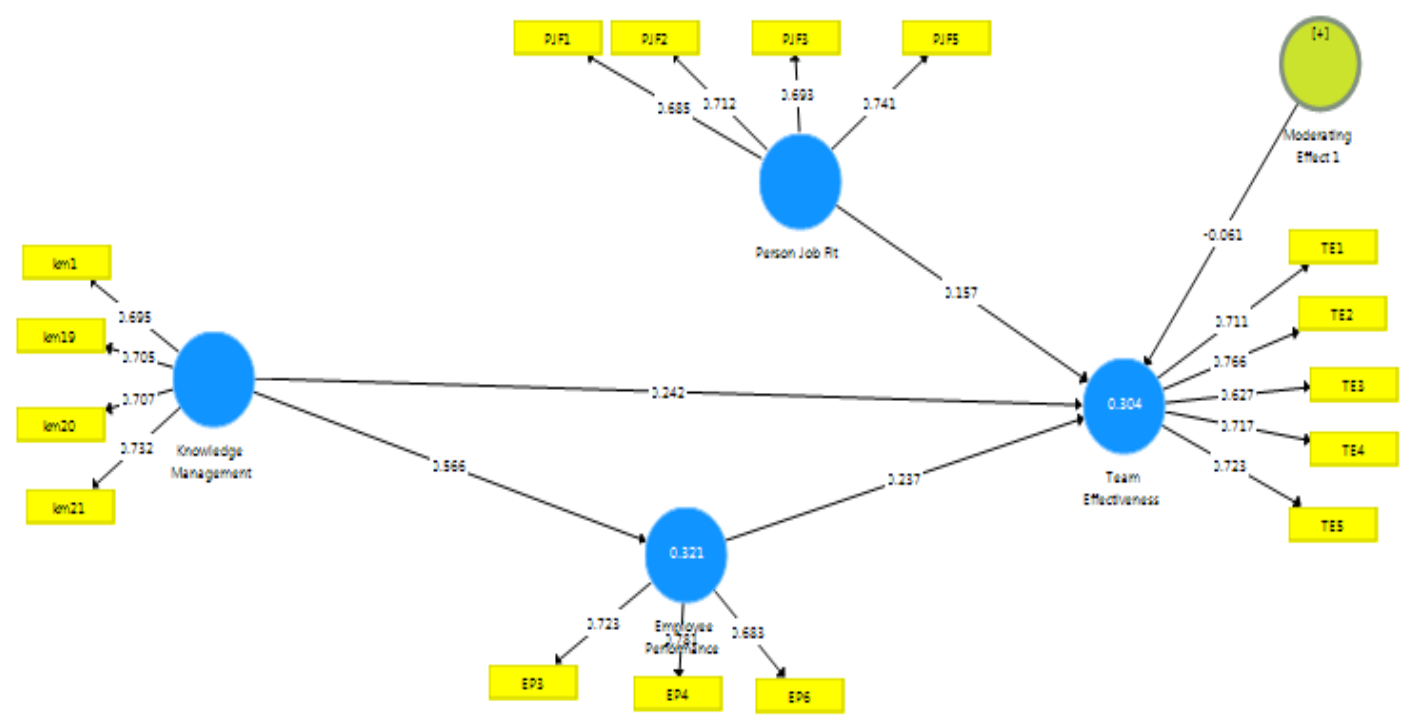

In the above figure moderation, effects are applied to team effectiveness. Then Bootstrapping test is run through which the values between the linkages are calculated. In this way, the acceptance or rejection of the hypothesis is also analyzed.

Table-5 Hypotheses Testing

\begin{tabular}{llllll}
\hline Linkages & Beta value & Std Error & t-value & P-value & Decision \\
\hline EP $>>$ TE & 0.283 & 0.097 & 2.923 & $\mathbf{0 . 0 0 4}$ & Supported \\
KM $>$ EP & 0.430 & 0.061 & 7.107 & $\mathbf{0 . 0 0 0}$ & Supported \\
KM $>$ TE & 0.280 & 0.082 & 3.399 & $\mathbf{0 . 0 0 1}$ & Supported \\
\hline
\end{tabular}

Here the direct linkages between Knowledge management, Employee Performance, personal job fit, and team effectiveness.

By using the Smart PLS software the direct linkages are calculated in the structural model where the p-value of all the linkages is above zero is the hypothesis is supported.

\begin{tabular}{|c|c|c|c|c|c|c|}
\hline Linkages & $\begin{array}{l}\text { Beta } \\
\text { value }\end{array}$ & $\begin{array}{l}\text { Std } \\
\text { Error }\end{array}$ & t-value & P value & Confidence level & Decision \\
\hline $\mathrm{KM} \rightarrow \mathrm{EP}_{-}->\mathrm{TE}$ & 0.122 & 0.045 & 2.722 & 0.007 & $\begin{array}{ll}\mathbf{2 . 5 \%} & \mathbf{9 7 . 5 \%} \\
0.019 & 0.206\end{array}$ & Accepted \\
\hline
\end{tabular}

Mediator: Employee performance

To determine the hypothesized relationship and to define the mediating role of employee performance and its linkage, smart PLS is used and a bootstrapping test is run. As the above results show that the p-value is above zero and the confidence level of the linkage supported the hypothesis.

\section{Conclusion}

This study focused on employees of private banks of Rawalpindi and Islamabad. The study aimed to explore the relationship between Knowledge Management and Team effectiveness as well as the 
mediating role of Employee performance and moderating role of Person job fit also checked in the relationship between Knowledge Management and Team effectiveness. Five major hypotheses were established to conduct the present study and all hypotheses were accepted and positively related to each other. The positive relation between knowledge management and Team effectiveness was also identified. There is also a positive mediating impact on Employee performance. The positive and significant moderating role of employee performance was also identified in the relationship between Knowledge management and team effectiveness.

\section{References:}

Arora, R., \& Stoner, C. (1996). The effect of perceived service quality and name familiarity on the service selection decision. Journal of Services Marketing.

Arora, R., \& Stoner, C. (1996). The effect of perceived service quality and name familiarity on the service selection decision. Journal of Services Marketing.

Barney, J. (1991). Firm resources and sustained competitive advantage. Journal of Management, 17(1), 99-120

Bhat, Z. H., \& Rainayee, R. A. (2019). Examining the mediating role of person-job fit in the relationship between training and performance: A civil servant perspective. Global Business Review, 20(2), 529-548.

Borman, W. C., \& Motowidlo, S. J. (1997). Task performance and contextual performance: The meaning for personnel selection research. Human performance, 10(2), 99-109.

Caldwell, D. F., \& O'Reilly III, C. A. (1990). Measuring person-job fit with a profile-comparison process. Journal of applied psychology, 75(6), 648

Conger, J. A., \& Kanungo, R. N. (1988). The empowerment process: Integrating theory and practice. Academy of management review, 13(3), 471-48

Cordery, J. L., Mueller, W. S., \& Smith, L. M. (1991). Attitudinal and behavioral effects of an autonomous group working: A longitudinal field study. Academy of management journal, 34(2), 464-476.

Culp, G., \& Smith, A. (2001). Understanding psychological type to improve project team performance. Journal of Management in Engineering, 17(1), 24-33.

Davenport, S., Davies, J., \& Grimes, C. (1998). Collaborative research programs: building trust from the difference. Technovation, 19(1), 31-40

Deeter-Schmelz, D. R., Kennedy, K. N., \& Ramsey, R. P. (2002). Enriching our understanding of student team effectiveness. Journal of Marketing Education, 24(2), 114-124.

Dimitriadis, E., White, C. A., Jones, R. L., \& Salamonsen, L. A. (2005). Cytokines, chemokines, and growth factors in endometrium related to implantation. Human reproduction update, 11(6), 613-630.

Drucker, P. F. (1994). The theory of the business.

Edwards, J. R. (1991). Person-job fit: A conceptual integration, literature review, and methodological critique. John Wiley \& Sons.

Greiner, M. E., Böhmann, T., \& Krcmar, H. (2007). A strategy for knowledge management. Journal of knowledge management.

Güngör, P. (2011). The relationship between the reward management system and employee performance with the mediating role of motivation: A quantitative study on global banks. Procedia-Social and Behavioral Sciences, 24, 1510-1520.

Hlupic, V., Pouloudi, A., \& Rzevski, G. (2002). Towards an integrated approach to knowledge management: 'hard', 'soft, and 'abstract issues. Knowledge and Process Management, 9(2), 90-102.

Kheng, Y. K., June, S., \& Mahmood, R. (2013). The determinants of innovative work behavior in the knowledge-intensive business services sector in Malaysia. Asian Social Science, 9(15), 47.

Kondrasuk, J. N. (2011). So what would an ideal performance appraisal look like? Journal of Applied Business and Economics, 12(1), 57-71.

Kotler, P., Armstrong, G., Saunders, J., \& Wong, V. (2002). Principles of Marketing, 3rd European edition. Harlow et al.

Kristof, A. L. (1996). Person- organization fit: An integrative review of its conceptualizations, measurement, and implications. Personnel Psychology, 49(1), 1-49. 
Lucius, R. H., \& Kuhnert, K. W. (1997). Using sociometry to predict team performance in the workplace. The journal of Psychology, 131(1), 21-32.

Luthans, F., \& Stajkovic, A. D. (1999). Reinforce for performance: The need to go beyond pay and even rewards. Academy of Management Perspectives, 13(2), 49-57

O'dell, C., \& Grayson, C. J. (1998). If only we knew what we know: Identification and transfer of internal best practices. California management review, 40(3), 154-174. Pleatsikas, C., \&, D. (2001). The analysis of the market definition and market power in the context of rapid innovation. International Journal of Industrial Organization, 19(5), 665-693.

Riege, A., \& Lindsay, N. (2006). Knowledge management in the public sector: stakeholder partnerships in public policy development. Journal of knowledge management.

Saks, A. M., \& Ashforth, B. E. (1997). Organizational socialization: Making sense of the past and present as a prologue for the future. Journal of Vocational Behavior, 51(2), 234-279.

Saks, A. M., \& Ashforth, B. E. (1997). Organizational socialization: Making sense of the past and present as a prologue for the future. Journal of Vocational Behavior, 51(2), 234-279.

Saks, A. M., \& Ashforth, B. E. (2002). Is job search related to employment quality? It all depends on the fit. Journal of Applied Psychology, 87(4), 646.

Shalley, C. E., \& Gilson, L. L. (2004). What leaders need to know: A review of social and contextual factors that can foster or hinder creativity? The leadership quarterly, 15(1), 33-53.

Shea, G. P., \& Guzzo, R. A. (1987). Groups as human resources. Research in personnel and human resources management, 5, 323-356.

Stein, $R$. T. (1975). Identifying emergent leaders from verbal and nonverbal communications. Journal of Personality and Social Psychology, 32(1), 125.

Viswesvaran, C., \& Ones, D. S. (2000). Measurement error in "Big Five Factors" personality assessment: Reliability generalization across studies and measures. Educational and Psychological Measurement, 60(2), 224-235.

Wanous, J. P. (1980). The Entry of Newcomers into Organizations. MICHIGAN STATE UNIV EAST LANSING DEPT OF PSYCHOLOGY.

Werbel, J. D., \& Gilliland, S. W. (1999). Person-environment fit in the selection process.

Wood, F., \& Sangster, A. (2002). Frank Wood's Business Accounting 2. Financial Times/Prentice Hall.

Woodman, R. W., Sawyer, J. E., \& Griffin, R. W. (1993). Toward a theory of organizational creativity. Academy of management review, 18(2), 293-321. 